\title{
Synthesis and Structural Characterization of CSH-Phases in the Range of C/S = $0.41-1.66$ at Temperatures of the Tobermorite Xonotlite Crossover
}

\author{
Andrea Hartmann1, David Schulenberg' ${ }^{2}$, Josef-Christian Buhl1 \\ ${ }^{1}$ Institut für Mineralogie, LUH, Hannover, Germany \\ ${ }^{2}$ Institut für Baustoffe, Bauphysik und Bauchemie, TUHH, Hamburg, Germany \\ Email:a.hartmann@mineralogie.uni-hannover.de
}

Received 30 September 2015; accepted 14 November 2015; published 20 November 2015

Copyright (C) 2015 by authors and Scientific Research Publishing Inc.

This work is licensed under the Creative Commons Attribution International License (CC BY). http://creativecommons.org/licenses/by/4.0/

\section{(c) (i) Open Access}

\begin{abstract}
Calcium-Silicate-Hydrate-phases (CSH-phases) are important binding agents of building materials. The synthesis of CSH phases and their structural characterization was done to investigate the crystallization in dependence of an increasing $\mathrm{CaO} / \mathrm{SiO}_{2}$ ratio (C/S ratios) from 0.41 up to 1.66 at temperatures in the crossover region of tobermorite to xonotlite $\left(180^{\circ} \mathrm{C}\right.$ and $\left.230^{\circ} \mathrm{C}\right)$. Parallel runs with the same $\mathrm{C} / \mathrm{S}$ ratio but on the one hand with constant mass of quartz and variation of lime and on the other hand under reverse conditions (constant mass of lime but variable amounts of quartz) were performed at both temperatures. The aim was to clarify the connections of crystallization mechanism and kinetics of phase formation with structure, crystallinity and morphology of the CSH's in the mentioned C/S ratio for both temperatures in the tobermorite-xonotlite crossover region. The parallel experiments with different mass ratios of the educts are important to study the influence of time evaluation of supersaturation within the solution under the peculiarities of the retrograde solubility of lime but accelerated solubility of quartz. The products were characterized by XRD, SEM/EDX, FTIR and ${ }^{29}$ Si MAS NMR spectroscopy (using the Q-site nomenclature [1]). The experiments could clarify some important connections of crystallization process and the reaction pathway.
\end{abstract}

\section{Keywords}

CSH-Phases, Tobermorite, Xonotlite, C/S Ratio, ${ }^{29}$ Si MAS NMR Spectroscopy 


\section{Introduction}

Calcium-Silicate-Hydrate-phases (CSH-phases) are important binding agents in building materials, like concrete and limesand stone. CSH phases with different chemical compositions regarding the $\mathrm{CaO}$ to $\mathrm{SiO}_{2}$ ratio (C/S-ratio) were crystallized by hydrothermal reaction of $\mathrm{CaO}, \mathrm{SiO}_{2}$ and $\mathrm{H}_{2} \mathrm{O}$ [2] [3]. The crystallization of $\mathrm{CSH}$-phases depends on the C/S ratio of the educts, the reaction temperature and the reaction time. These parameters influence the formation of structure type, crystallinity and crystal morphology of the CSH-phases, e.g. in limesand stone, in the free pore space between the quartz cores.

As $\mathrm{SiO}_{2}$ source quartz sand is mainly used. $\mathrm{CaO}$ (calcinated lime) is obtained by calcination of carbonate $\left(\mathrm{CaCO}_{3}\right)$ at $900^{\circ} \mathrm{C}$. Reaction of the latter with water leads to the formation of portlandite $\left(\mathrm{Ca}(\mathrm{OH})_{2}\right)$. Under hydrothermal conditions $\mathrm{Ca}(\mathrm{OH})_{2}$ and $\mathrm{SiO}_{2}$ react to $\mathrm{CSH}$-phases. The solubility of the educts plays an important role in the crystallization of CSH. The solubility of quartz increases with temperature, while $\mathrm{Ca}(\mathrm{OH})_{2}$ has a decreasing solubility in water (retrograde solubility) [4]. At the beginning of the hydrothermal reaction between $\mathrm{Ca}(\mathrm{OH})_{2}$ and $\mathrm{SiO}_{2}$ in autoclaves the solution is saturated with lime [4]. Ca-rich phases crystallize at first during the hydrothermal process, e.g. $\alpha-\mathrm{C}_{2} \mathrm{SH}$, followed by the amorphous gel-like CSH-II [5]-[7]. Thereon the crystalline CSH-I occurs. The next step is the formation of band-like crystals of $11 \AA$ tobermorite and long needles of xonotlite [2] [7]. The final phase is gyrolite with hexagonal plates [2]. Mörtel (1980) described the following crystallization steps of the formation of CSH-phases [2]:

$$
\alpha-\mathrm{C}_{2} \mathrm{SH} \rightarrow \mathrm{CSH} \mathrm{I} \rightarrow \mathrm{CSH} \text { II } \rightarrow 11 \AA \text { tobermorite } \rightarrow \text { xonotlite } \rightarrow \text { gyrolite }
$$

The most important $\mathrm{CSH}$-phase in building materials, like limesand stone, is the $11 \AA$ tobermorite $\left(\mathrm{Ca}_{5}\right.$ $\left[\mathrm{Si}_{6} \mathrm{O}_{16}(\mathrm{OH})_{2}\right] \times 2 \mathrm{H}_{2} \mathrm{O}$ ) with a band- or card-shaped morphology. The tobermorite crystals lead to the cementation of the quartz cores and determine the stability of the building material. $11 \AA$ tobermorite is a stable CSHphase at a $\mathrm{C} / \mathrm{S}$-ratio of 0.83 and thermodynamically calculations gave a range of stability starting at $90^{\circ} \mathrm{C}$ [4]. In practice crystallization temperatures around $160^{\circ} \mathrm{C}$ yield to tobermorite crystals of proper quality [5] [6].

The crystal structure of natural $11 \AA$ tobermorite was first described by Megaw and Kelsey (1956) [8], later by Hamid (1981) [9] as an orthorhombic structure as well as Merlino et al. (1999, 2000 and 2001) even for clinotobermorite and polytypes [10]-[12]. The structure of $11 \AA$ tobermorite consists of alternating $\left(\mathrm{Si}_{3} \mathrm{O}_{9}\right)^{6}$-chains ("Dreiereinfachketten"), sheets of $\mathrm{CaO}$-octahedra and intermediate layers of $\mathrm{CaO}$ and $\mathrm{H}_{2} \mathrm{O}$ [9]. Each "Dreiereinfachkette" is orientated to the b-axis and consists of two paired tetrahedra pointing towards the Ca-layer and one bridging tetrahedron orientated to the intermediate layer [1] [8]-[11]. The notation of the different types of tobermorite (e.g. $9 \AA$ tobermorite, $11 \AA$ tobermorite) is based on the distance $(\AA)$ between the two layers of $\mathrm{CaO}$ polyhedra. The $\mathrm{Ca}^{2+}$ cations of the intermediate layer (consisting of $\mathrm{H}_{2} \mathrm{O}$ molecules and $\mathrm{Ca}^{2+}$ cations) compensate the negative charge of the $\left(\mathrm{Si}_{3} \mathrm{O}_{9}\right)^{6}$-chains ("Dreiereinfachketten") and arrange the connection between the "calcium-silicate-layers".

Xonotlite $\left(\mathrm{Ca}_{6} \mathrm{Si}_{6} \mathrm{O}_{17}(\mathrm{OH})_{2}\right)$ is a stable CSH-phase with needle-like morphology [2] and thermodynamic calculations for a C/S-ratio of 1.0 yield to $90^{\circ} \mathrm{C}$ as the lowermost temperature of stability [4]. Below $100^{\circ} \mathrm{C}$ xonotlite transforms into tobermorite. Usually temperatures tight above $200^{\circ} \mathrm{C}$ yield to xonotlite crystals of proper quality [5]-[7]. An early structural investigation was performed by Mamedov and Belov (1955) [13] and later by Kudoh and Takeuchi (1979) [14]. In a later work Hejny and Armbruster (2001) [15] described the structure of xonotlite polytypes. More or less disordered polytype structures of xonotlite basically consist of layers of $\mathrm{CaO}-$ polyhedra (Ca-octahedra and $\mathrm{Ca}$ in sevenfold coordination) linked with silicate double chains $\left(\mathrm{Si}_{6} \mathrm{O}_{17}\right)$, the "Dreierdoppelketten". The CaO-polyhedral layers are orientated in a-b-plane and are stacked along the c-direction. The structure of xonotlite shows close resemblance to the structure of wollastonite, which even exhibits "Dreierdoppelketten" [16].

Hillebrandite $\left(\mathrm{Ca}_{2} \mathrm{SiO}_{3}(\mathrm{OH})_{2}\right)$ can be synthesized in the temperature range of $175^{\circ} \mathrm{C}-250^{\circ} \mathrm{C}$ [4] as long fibers with a $\mathrm{C} / \mathrm{S} \geq 2.0$. The crystal structure of hillebrandite was described by Heller (1953) [17] and later by Dai and Post (1995) [18]. A three dimensional network is formed by Ca-polyhedra. This network exhibits channels along the a-axis, which contains wollastonite like silicate double chains.

Various studies on synthesis and properties of CSH-phases like tobermorite, xonotlite, hillebrandite are available in the literature since decades. Beside comprehensive former studies like [2] [4] [6] [19] [20] [21] there are interesting recent works like the extensive and detailed study of Garbev [22] on hydrothermal synthesis of CSH's, synthesis studies of Hartmann et al. on tobermorites [5] [6] [23] [24], studies of Black et al. [25] or the experimental research of Spudulis et al. [26] in the special case of xonotlite beside many others. 
Despite all those accurate investigations there are nevertheless some important questions concerning the connections of crystallization mechanism and kinetics of phase formation with structure, crystallinity and morphology of the CSH's. Especially our knowledge on certain structural features connected with temperature dependent phase transitions and crystallization process from the 14 tobermorites to the 11 phase and to xonotlite in structural relation to wollastonite types can be further mentioned here beside many other questions on this broad field of CSH-phases.

In this sense the present work investigates CSH crystallization in view of two special points: Firstly we investigate the temperature interval of the crossover reaction from tobermorite to xonotlite to get more information on structure-temperature relations of both CSH's during this process step. And secondly we use the experimental approach of synthesis of two parallel rows with same C/S ratios but different mass ratios of the individual raw materials. Sample 1) under constant amount of quartz and variation of lime and sample 2) under reverse conditions (constant mass of lime but variable amounts of quartz). Those parallel series with different amounts of initial components are of interest as time dependent allocations of the total amounts of calcium and silicate ions into the solution can be studied that way. CSH formation under the peculiarities of a retrograde solubility of lime but accelerated solubility of quartz is a diffusion dependant process under kinetic control and is thus strongly influenced by the evaluation of concentration of the components in the solution. The aim of the present work is the receipt of new information on the whole crystallization process. Seeding behaviour and crystal growth mainly depend on the temporary evaluation of supersaturation within the solution [27].

\section{Experimental}

\subsection{Syntheses}

The syntheses of the CSH-phases were done with powdered quartz $\left(\mathrm{SiO}_{2}\right)$ of particle size $>230$ mesh (FLUKA $83,340)$ and calcium oxide $(\mathrm{CaO})$, obtained by calcium carbonate $\left(\mathrm{CaCO}_{3}\right.$ Merck 1.02066$)$ calcinated for $3 \mathrm{~h}$ at $1000^{\circ} \mathrm{C}$. Two synthesis series at different temperatures were done (series $1: 180^{\circ} \mathrm{C}$ and series $2: 230^{\circ} \mathrm{C}$ ). The $\mathrm{C} / \mathrm{S}$ ratios were varied from 0.41 to 1.66 as $\mathrm{CSH}$ phases were also found in nature in this broad range like okenite $(\mathrm{C} / \mathrm{S}=0.5)$ or foshagite $(\mathrm{C} / \mathrm{S}=1.67)$ [4]. At both temperatures and for each $\mathrm{C} / \mathrm{S}$ ratio parallel syntheses were performed. Experiments a: Synthesis under insertion of a constant amount of quartz and variation of lime and experiments b: Synthesis by using a constant mass of lime but a variable amount of quartz.

For each synthesis the educts were filled into $50 \mathrm{ml}$ steel autoclaves with Teflon liners and distilled water was added. The water portion was calculated to reach a liquid to solid ratio of 7.5 in each experiment. The hydrothermal treatment in an oven was done at $180^{\circ} \mathrm{C}$ and $230^{\circ} \mathrm{C}$ for $40.5 \mathrm{~h}$. Afterwards the products were filtered and washed with distilled water and dried for $24 \mathrm{~h}$ at $80^{\circ} \mathrm{C}$. The experimental details of the two synthesis series are summarized in Table 1 and Table 2.

\subsection{Analytical Methods}

The analysis of the synthesis products was done by XRD, SEM/EDX, FTIR spectroscopy and ${ }^{29}$ Si MAS NMR

Table 1. Experimental details of series $1\left(180^{\circ} \mathrm{C}\right)$.

\begin{tabular}{ccccc}
\hline Sample & C/S ratio & $\mathbf{S i O}_{2}(\mathbf{g})$ & $\mathbf{C a O}(\mathbf{g})$ & $\mathbf{H}_{2} \mathbf{O}(\mathbf{m l})$ \\
\hline $1.1 \mathrm{a}^{*}$ & 0.41 & 1.50 & 0.58 & 15.6 \\
$1.1 \mathrm{~b}^{*}$ & & 3.00 & 1.16 & 31.2 \\
$1.2 \mathrm{a}$ & 0.55 & 1.50 & 0.77 & 17.0 \\
$1.2 \mathrm{~b}$ & & 2.25 & 1.16 & 25.6 \\
$1.3 \mathrm{ab}$ & 0.83 & 1.50 & 1.50 .0 & 24.3 \\
$1.4 \mathrm{a}$ & 1.24 & 1.00 & 1.74 & 16.2 \\
$1.4 \mathrm{~b}$ & & 1.50 & 1.16 & 28.7 \\
$1.5 \mathrm{a}$ & 1.66 & 0.75 & 2.33 & 1.16 \\
$1.5 \mathrm{~b}$ & & & & 14.3 \\
\hline
\end{tabular}

\footnotetext{
${ }^{*}$ a: synthesis with constant $\mathrm{SiO}_{2}$ content, b: synthesis with constant $\mathrm{CaO}$ content.
} 
Table 2. Experimental details of series $2\left(230^{\circ} \mathrm{C}\right)$.

\begin{tabular}{ccccc}
\hline Sample & C/S ratio & $\mathbf{S i O}_{2}(\mathbf{g})$ & $\mathbf{C a O}(\mathbf{g})$ & $\mathbf{H}_{2} \mathbf{O}(\mathbf{m l})$ \\
\hline $2.1 \mathrm{a}^{*}$ & 0.41 & 1.50 & 0.58 & 15.6 \\
$2.1 \mathrm{~b}^{*}$ & & 3.00 & 1.16 & 31.2 \\
$2.2 \mathrm{a}$ & 0.55 & 1.50 & 0.77 & 17.0 \\
$2.2 \mathrm{~b}$ & & 2.25 & 1.16 & 25.6 \\
$2.3 \mathrm{ab}$ & 0.83 & 1.50 & 1.16 & 20.0 \\
$2.4 \mathrm{a}$ & 1.24 & 1.50 & 1.74 & 24.3 \\
$2.4 \mathrm{~b}$ & & 1.00 & 1.16 & 16.2 \\
$2.5 \mathrm{a}$ & 1.66 & 1.50 & 2.33 & 28.7 \\
$2.5 \mathrm{~b}$ & & 0.75 & 1.16 & 14.3 \\
\hline
\end{tabular}

*a: synthesis with constant $\mathrm{SiO}_{2}$ content, b: synthesis with constant $\mathrm{CaO}$ content.

spectroscopy. For XRD measurements the X-Ray diffractometer PW1800 (Philips) was used. The CuKa X-rays were generated with a $\mathrm{Cu}$-anode $(40 \mathrm{kV}, 40 \mathrm{~mA})$ and a graphite-monochromator. The measurements were done with a $\theta / 2 \theta$-scan with 3900 steps over 10 hours and 50 minutes (step size $0.02^{\circ} 2 \theta$ and $10 \mathrm{~s}$ measuring time) in the range of $2^{\circ}-80^{\circ} 2 \theta$. The data were analyzed using the WinXPow software of Stoe \& Chi. The quantitative analysis was done by Rietveld refinement of X-ray powder data using the Topas 4.2 software (Bruker AXS). For analyzing the morphology and chemical composition of the synthesis products a scanning electron microscope (SEM) Jeol JSM-6390A with an accelerating voltage of $20 \mathrm{kV}$ or $30 \mathrm{kV}$ was used. The EDX analysis was done by a QUANTAX spectrometer with an X Flash M410 detector (Bruker). Therefore the samples were sputtered with a fine layer of gold to prevent electric charging during measurements. Therefore a signal of gold (Au) exists in each EDX spectrum. Infrared spectra were measured by a VERTEX 80 v FTIR-spectrometer (Bruker) and evaluated using the Opus software (Bruker). Therefore the samples were diluted by $\mathrm{KBr}$ (1 mg sample in 200 $\mathrm{mg} \mathrm{KBr}$ ), pressed into pellets and measured relatively to the $\mathrm{KBr}$ as a reference.

Selected samples were analyzed by ${ }^{29} \mathrm{Si}$ MAS NMR spectroscopy as high resolution NMR spectroscopy of this nucleus was shown to be a powerful method for structural characterization of CSH phases tobermorite [28] [29], xonotlite and hillebrandite [30]. An ASX400 WB FT-NMR spectrometer from Bruker at Ruhr University of Bochum was therefore inserted in our study. The spectra were recorded at $79.493 \mathrm{MHz}$. A pulse sequence with $4 \mu$ s pulse duration and $120 \mathrm{~s}$ pulse delay were used. The spinning frequency of $4 \mathrm{kHz}$ was revealed. Chemical shifts were related to tetramethylsilane standard (TMS).

\section{Results}

\subsection{XRD and SEM/EDX Analysis}

\subsubsection{Series $1\left(180^{\circ} \mathrm{C}\right)$}

1) Syntheses with constant mass of $\mathrm{SiO}_{2}$ (series 1.1a - 1.5a, Table 1):

The XRD results of series 1 with constant $\mathrm{SiO}_{2}$ are shown in Figure 1. The powder patterns of the synthesis products with $\mathrm{C} / \mathrm{S}$ ratios of 0.41 up to 1.66 exhibit strong signals of quartz (PDF 46-1045). The amount of quartz decreases with increasing C/S ratio. Beside quartz a high amount of $11 \AA$ tobermorite (PDF 45-1480) crystallizes in the syntheses with a $\mathrm{C} / \mathrm{S}$ value of 0.41 and highest amounts for the sample 1.2a of synthesis with $\mathrm{C} / \mathrm{S}=$ 0.55 . Also the synthesis with a C/S value of 0.83 shows signals of $\AA$ tobermorite. A small amount of xonotlite (PDF 23-125 [31]) is seen in the synthesis with a C/S value of 0.83 . Higher $\mathrm{C} / \mathrm{S}$ ratios of 1.34 and 1.66 led to the formation of calcite (PDF 10-400 [31]) and portlandite (PDF 4-733 [31]). A quantitative evaluation by Rietveld method of synthesis 1.2a is given in Table 3. This product was selected for Rietveld analysis as the sample with the highest amount of tobermorite in best quality of this series. The Rietveld analysis shows tobermorite as main phase beside small amounts of quartz and xonotlite (see Table 3).

2) Synthesis with constant mass of $\mathrm{CaO}$ (series $1.1 \mathrm{~b}-1.5 \mathrm{~b}$, Table 1):

The XRD results of series 1 with constant mass of $\mathrm{CaO}$ are shown in Figure 2. Strong signals of quartz can 


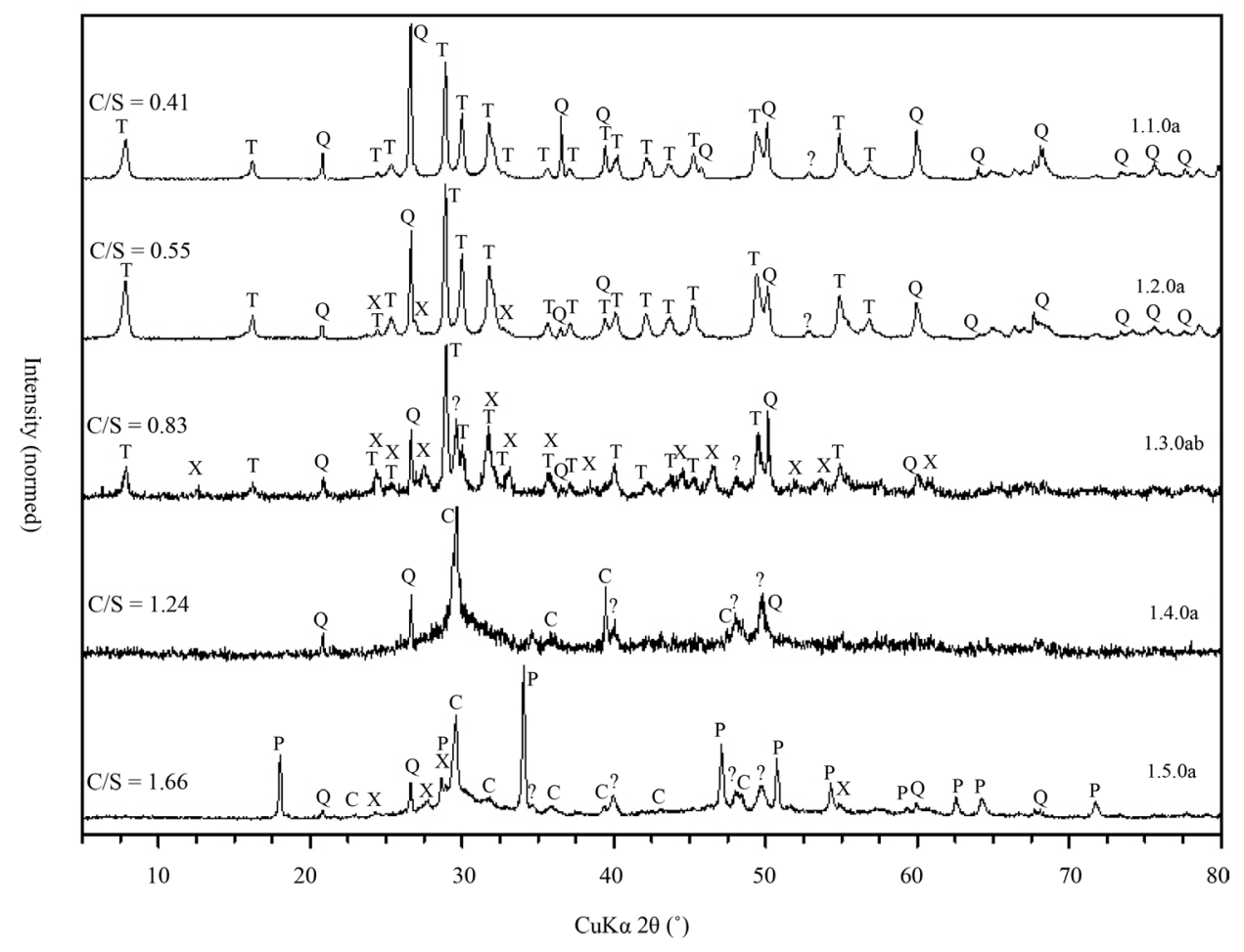

Figure 1. X-ray diffractogram of syntheses at $180^{\circ} \mathrm{C}$ (series 1 a) with increasing $\mathrm{C} / \mathrm{S}$ ratio and constant $\mathrm{SiO}_{2}$. Symbols: $11 \AA$ tobermorite (T), xonotlite (X), quartz (Q), calcite (C), portlandite (P), unknown phase (?).

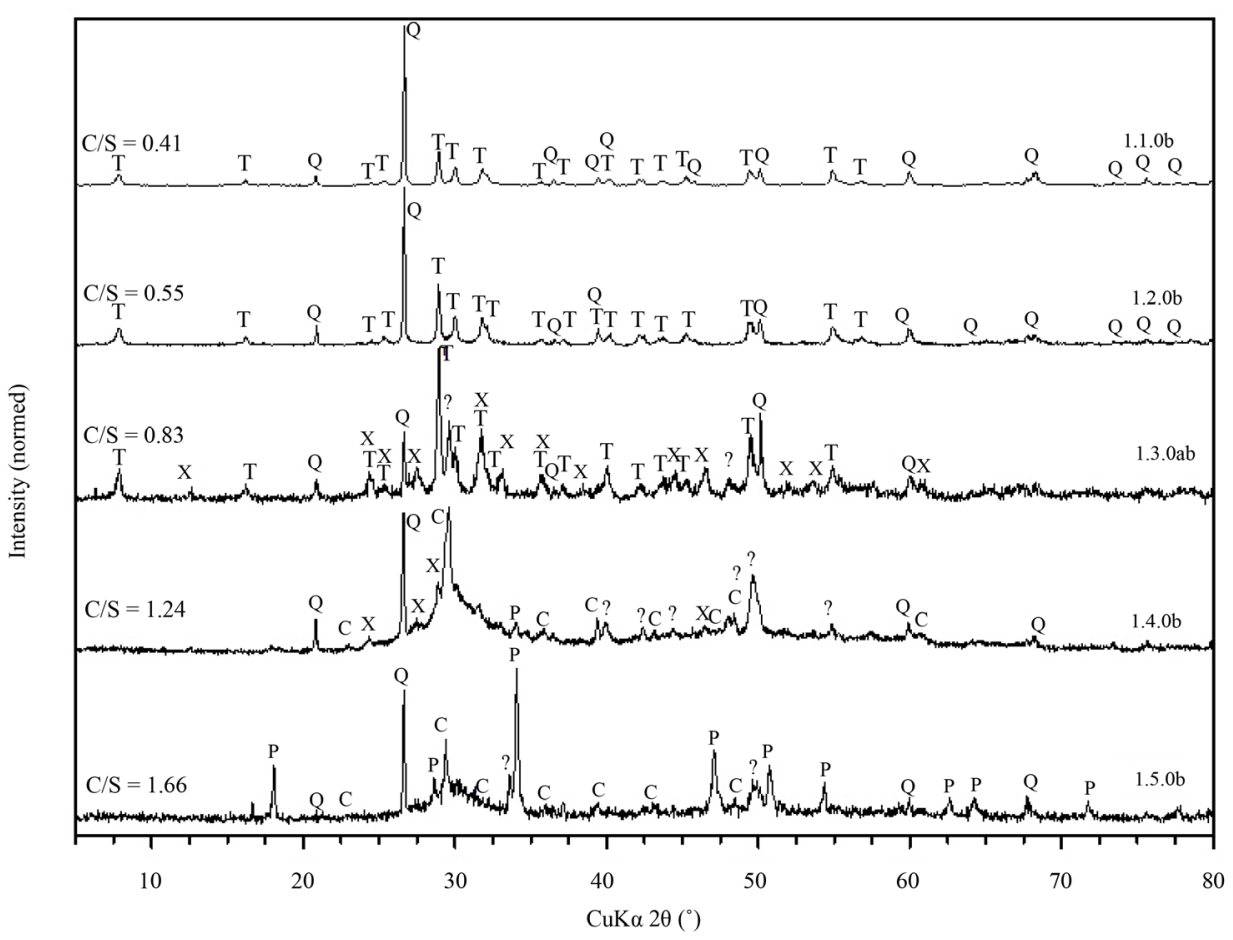

Figure 2. X-ray diffractogram of syntheses at $180^{\circ} \mathrm{C}$ (series $1 \mathrm{~b}$ ) with increasing $\mathrm{C} / \mathrm{S}$ ratio and constant CaO. Symbols: $11 \AA$ tobermorite (T), xonotlite (X), quartz (Q), calcite (C), portlandite (P), unknown phase (?). 
Table 3. Quantitative phase analysis of the synthesis product 1.2 a.

\begin{tabular}{ccc}
\hline Phase & Composition & Amount (M.-\%) \\
\hline 11 A tobermorite & $\mathrm{C}_{5} \mathrm{~S}_{6} \mathrm{H}_{5}$ & 91 \\
xonotlite & $\mathrm{C}_{6} \mathrm{~S}_{6} \mathrm{H}_{6}$ & 3 \\
quartz & $\mathrm{SiO}_{2}$ & 6 \\
\hline
\end{tabular}

be seen in the syntheses with $\mathrm{C} / \mathrm{S}$ ratios of 0.41 to 1.66 . In contrast to the syntheses series with constant $\mathrm{SiO}_{2}$ the amount of quartz did not decrease with increasing C/S values but for the product of C/S 0.83 lowest amount could be found.

With respect to the series with constant mass of $\mathrm{SiO}_{2}$ also in the experiments with constant CaO content signals of $11 \AA$ tobermorite are observed in the powder patterns of the products from educts with the C/S values $0.41,0.55$ and 0.83 but all are less intensive compared to the patterns of synthesis products, starting with constant mass of $\mathrm{SiO}_{2}$. In contrast, remarkable intense signals of xonotlite occur in the XRD pattern of samples of $\mathrm{C} / \mathrm{S}$ values 0.83 and 1.24. Again highest C/S values 1.24 and 1.66 led to the formation of calcite, whereas portlandite crystallized only in the series with a $\mathrm{C} / \mathrm{S}$ value of 1.66 .

For a quantitative evaluation by Rietveld analysis the product of synthesis 1.3ab was selected because of its optimal crystallization with highest parts of CSH phases but lowest content of remaining quartz. The refinements yield to $11 \AA$ tobermorite as main phase beside a somewhat smaller amount of xonotlite. Quartz was again detected only on very low scale as in sample 1.2a. All quantitative values are summarized in Table 4.

SEM/EDX-analysis was performed and data of the optimal products of the $180^{\circ} \mathrm{C}$ series (sample $1.2 \mathrm{a}$ and 1.3ab, Table 1 as well as Table 3 and Table 4) are shown in the following figures for further discussion of our results.

Figure 3 shows selected images of the SEM analysis of sample 1.2a.

The SEM image Figure 3 (top) of sample 1.2a, (C/S = 0.55) shows large band-like crystals of tobermorite with a size of about $4 \mu \mathrm{m}$. The typical card-like morphology of tobermorite crystals can be clearly seen in Figure 3 bottom. The tobermorite crystals grew into the free pore space between the quartz cores. The EDX analysis (Figure 4) also exhibits typical intensity distributions of Si and Ca signals for CSH-phases in the C/S interval $0.8<\mathrm{C} / \mathrm{S}<1.0$. A $\mathrm{C} / \mathrm{S}$ ratio of 0.83 was calculated as medium value from five EDX measurements by area analysis. The formation of tobermorite of ideal $\mathrm{C} / \mathrm{S}$ can be stated there from. It can be concluded that despite the $\mathrm{C} / \mathrm{S}$ of the starting batch of 0.55 , crystals with the higher ratios were formed. No further impurities were found according to this analysis within the sample.

The following Figure 5 shows results of the SEM analyses of the sample 1.3ab.

The SEM images of sample 1.3ab, C/S = 0.83 (Figure 5) indicate needle- and band-like crystals with a size up to $7.5 \mu \mathrm{m}$. The EDX analysis (Figure 6) again exhibits typical intensity distributions of Si and Ca signals for $\mathrm{CSH}$-phases in the $\mathrm{C} / \mathrm{S}$ interval $0.8<\mathrm{C} / \mathrm{S}<1.0$. A C/S ratio of 1.09 was calculated from area analysis indicating the formation of remarkable parts of xonotlite. As in product 1.2a no further impurities were found according to this analysis within the sample.

\subsubsection{Series $2\left(230^{\circ} \mathrm{C}\right)$}

1) Syntheses with constant mass of $\mathrm{SiO}_{2}$ (series 2.1 a - 2.5 a, Table 2):

Figure 7 shows the XRD results of the syntheses of series 2 with constant mass of $\mathrm{SiO}_{2}$. In the synthesis product obtained from educts with a $\mathrm{C} / \mathrm{S}$ value of 0.4 quartz is the main phase. Beside quartz also a small amount of tobermorite and xonotlite can be detected. At higher C/S values from 0.55 up to 1.34 the signals of xonotlite increase and those of tobermorite strongly decrease. At a C/S ratio of 1.66 the CSH-phase hillebrandite (PDF 42-538 [31] is formed).

In contrast to the synthesis series 1 at $180^{\circ} \mathrm{C}$, the synthesis products of series 2 at $230^{\circ} \mathrm{C}$ show no formation of calcite and portlandite.

According to the high degree of crystallinity estimated from the powder pattern of Figure 7 the product 2.3ab was selected for further analysis. The results of quantitative phase analysis by Rietveld refinement are summarized in Table 5. The Rietveld analysis indicates crystallization of a high amount of xonotlite beside a few portion of quartz in sample 2.3ab. 


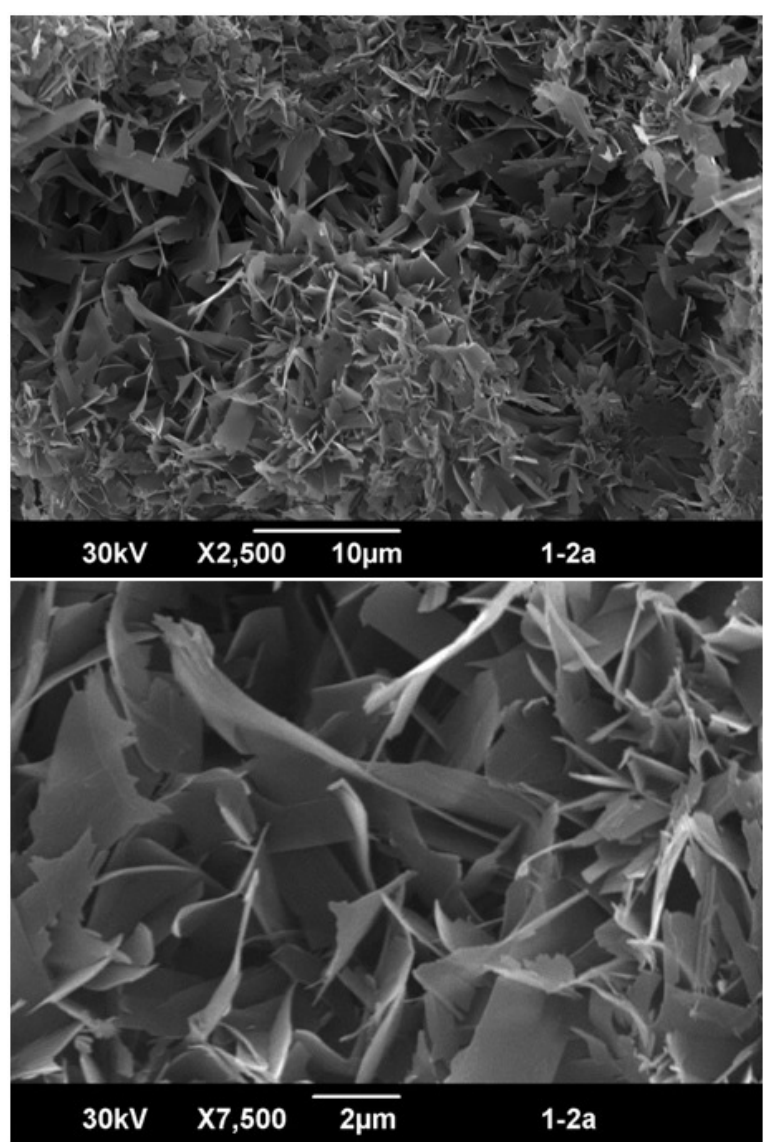

Figure 3. SEM image of sample $1.2 \mathrm{a}$ with $2500 \times$ magnification (top), $180^{\circ} \mathrm{C}, \mathrm{C} / \mathrm{S}=0.55$, main phase tobermorite and SEM image of sample 1.2a with $7500 \times$ magnification (bottom), $180^{\circ} \mathrm{C}, \mathrm{C} / \mathrm{S}=0.55$, main phase tobermorite.

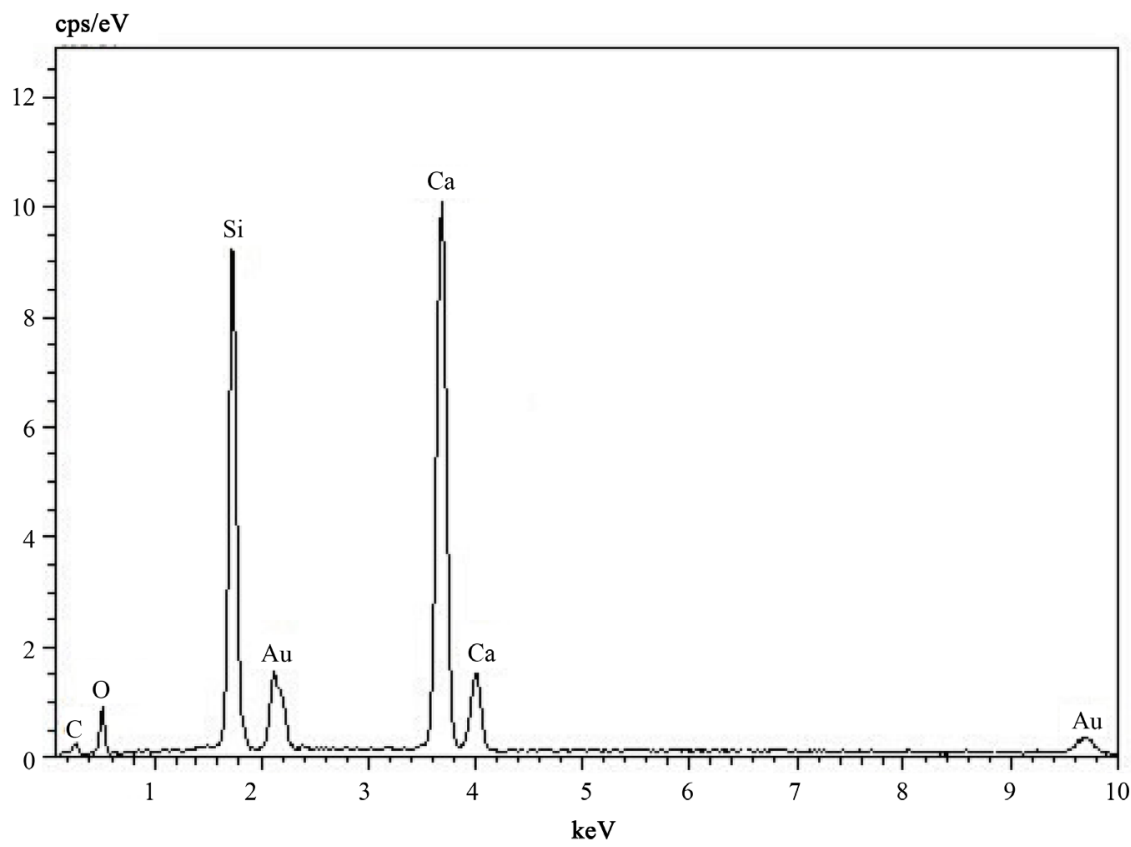

Figure 4. EDX spectrum of sample 1.2a. 

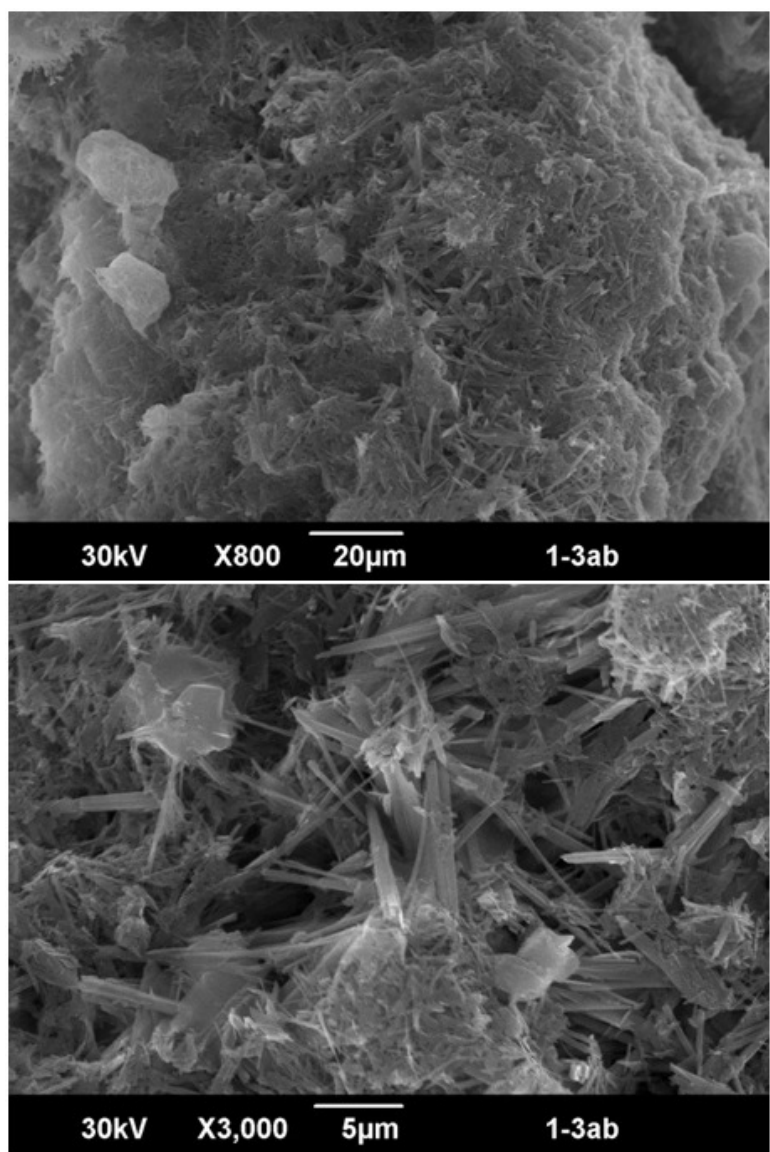

Figure 5. SEM image of sample $1.3 \mathrm{ab}$ with $800 \times$ magnification (top), $180^{\circ} \mathrm{C}, \mathrm{C} / \mathrm{S}=0.83$, main phases xonotlite and tobermorite) and SEM image of sample $1.3 \mathrm{ab}$ with $3000 \times$ magnification (bottom), $180^{\circ} \mathrm{C}, \mathrm{C} / \mathrm{S}=0.83$, main phases xonotlite and tobermorite.

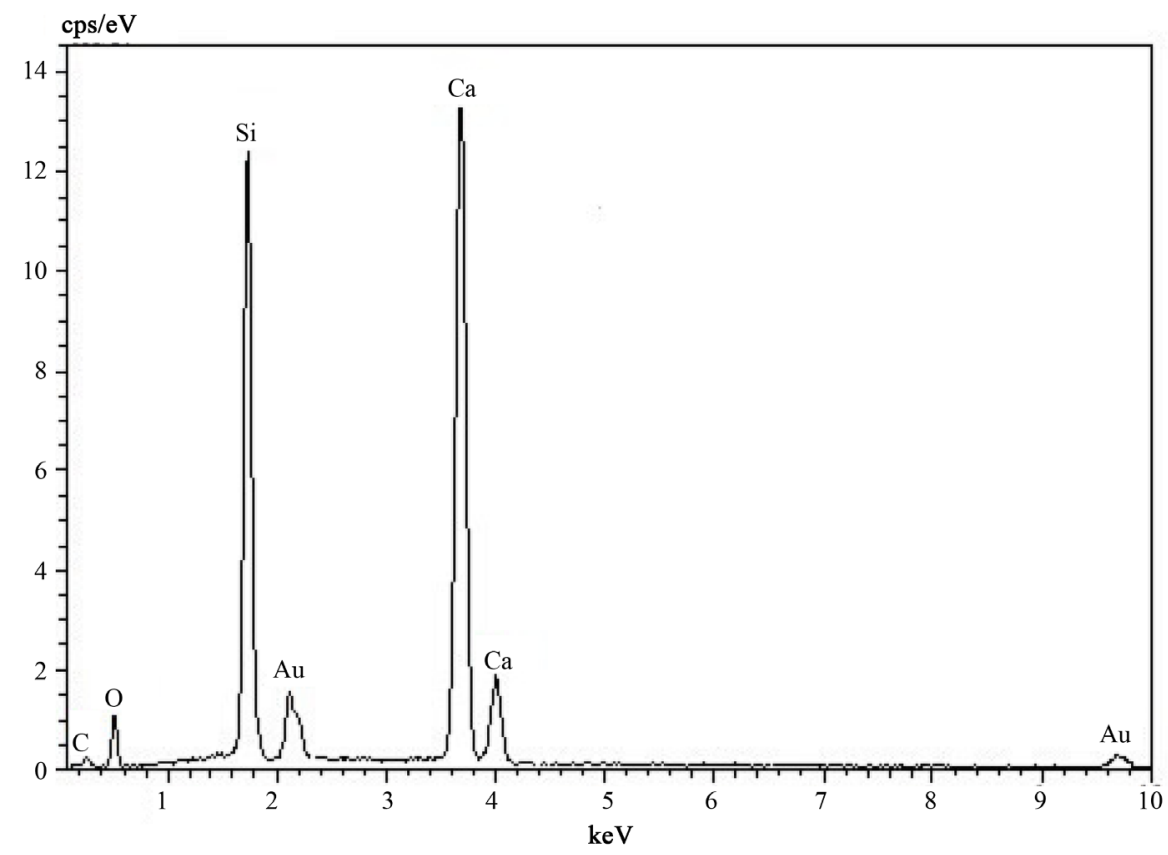

Figure 6. EDX spectrum of sample 1.3ab. 


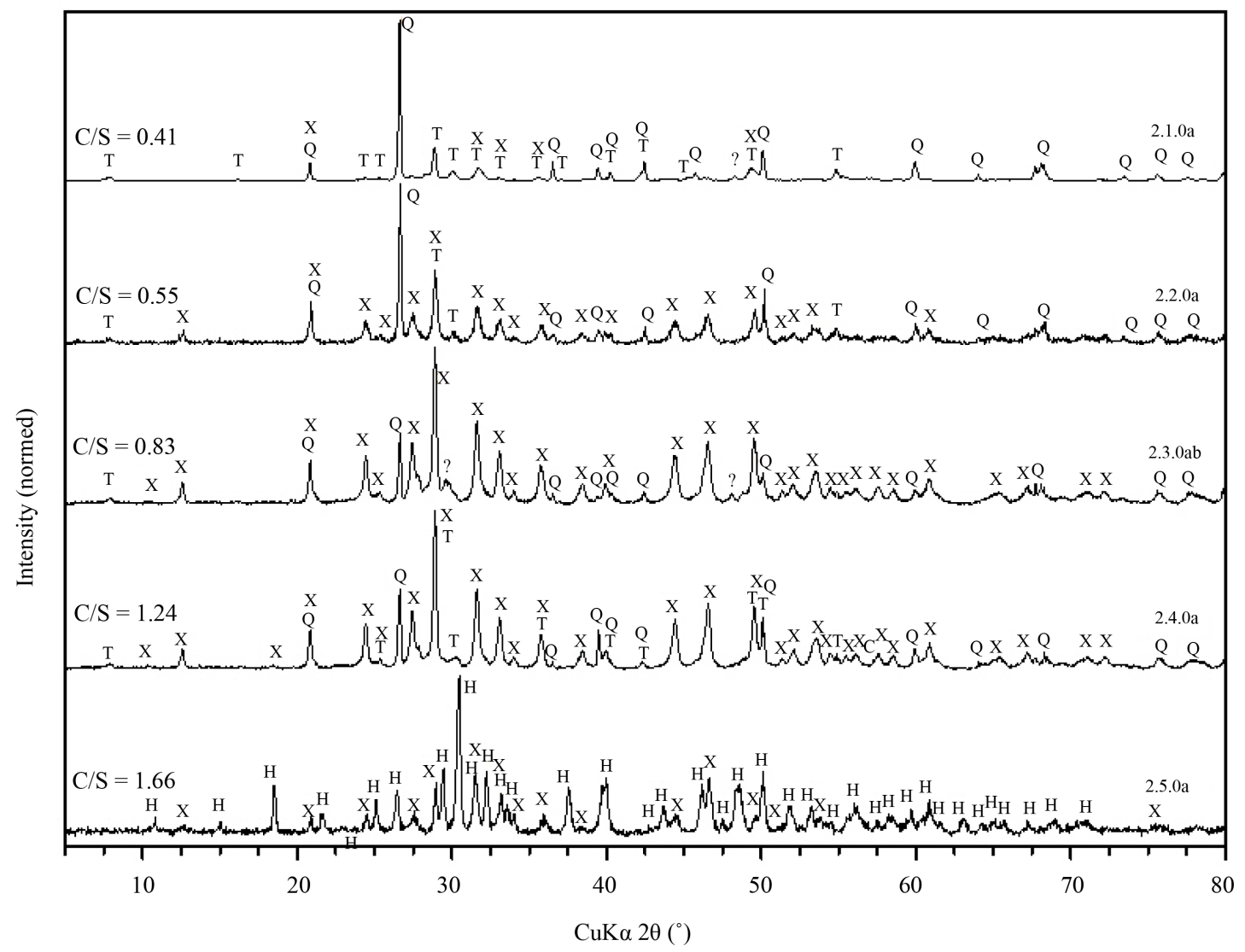

Figure 7. X-ray diffractogram of syntheses at $230^{\circ} \mathrm{C}$ (series 2 a) with increasing $\mathrm{C} / \mathrm{S}$ ratio and constant $\mathrm{CaO}$. Symbols: $11 \AA$ tobermorite $(\mathrm{T})$, xonotlite $(\mathrm{X})$, quartz $(\mathrm{Q})$, calcite $(\mathrm{C})$, portlandite $(\mathrm{P})$, unknown phase (?).

Table 4. Quantitative phase analysis of the synthesis product 1.3 ab.

\begin{tabular}{ccc}
\hline Phase & Composition & Amount (M.-\%) \\
\hline xonotlite & $\mathrm{C}_{6} \mathrm{~S}_{6} \mathrm{H}_{6}$ & 39 \\
$11 \AA$ tobermorite & $\mathrm{C}_{5} \mathrm{~S}_{6} \mathrm{H}_{5}$ & 58 \\
quartz & $\mathrm{SiO}_{2}$ & 3 \\
\hline
\end{tabular}

Table 5. Quantitative phase analysis of the synthesis product 2.3 ab.

\begin{tabular}{ccc}
\hline Phase & Composition & Amount (M.-\%) \\
\hline xonotlite & $\mathrm{C}_{6} \mathrm{~S}_{6} \mathrm{H}_{6}$ & 95 \\
quartz & $\mathrm{SiO}_{2}$ & 5 \\
\hline
\end{tabular}

2) Syntheses with constant mass of $\mathrm{CaO}$ (series $2.1 \mathrm{~b}-2.5 \mathrm{~b}$, Table 2):

In Figure 8 the XRD results of series 2 with constant mass of $\mathrm{CaO}$ are summarized. The diffractograms show resemblance to those of the syntheses with constant mass of $\mathrm{SiO}_{2}$. Again the signals of xonotlite increase with increasing $\mathrm{C} / \mathrm{S}$ ratios. At the highest $\mathrm{C} / \mathrm{S}$ ratios of 1.24 and 1.66 hillebrandite crystallized and also a small amount of calcite.

Due to the high degree of crystallinity sample $2.5 \mathrm{~b}$ was selected for Rietveld refinement. The Rietveld refinement shows hillebrandite as nearly main phase in the sample beside a few portions of calcite and a very low one of quartz. Quantitative data are summarized in Table 6.

The Figure 9 shows SEM photographs of sample 2.3ab. 


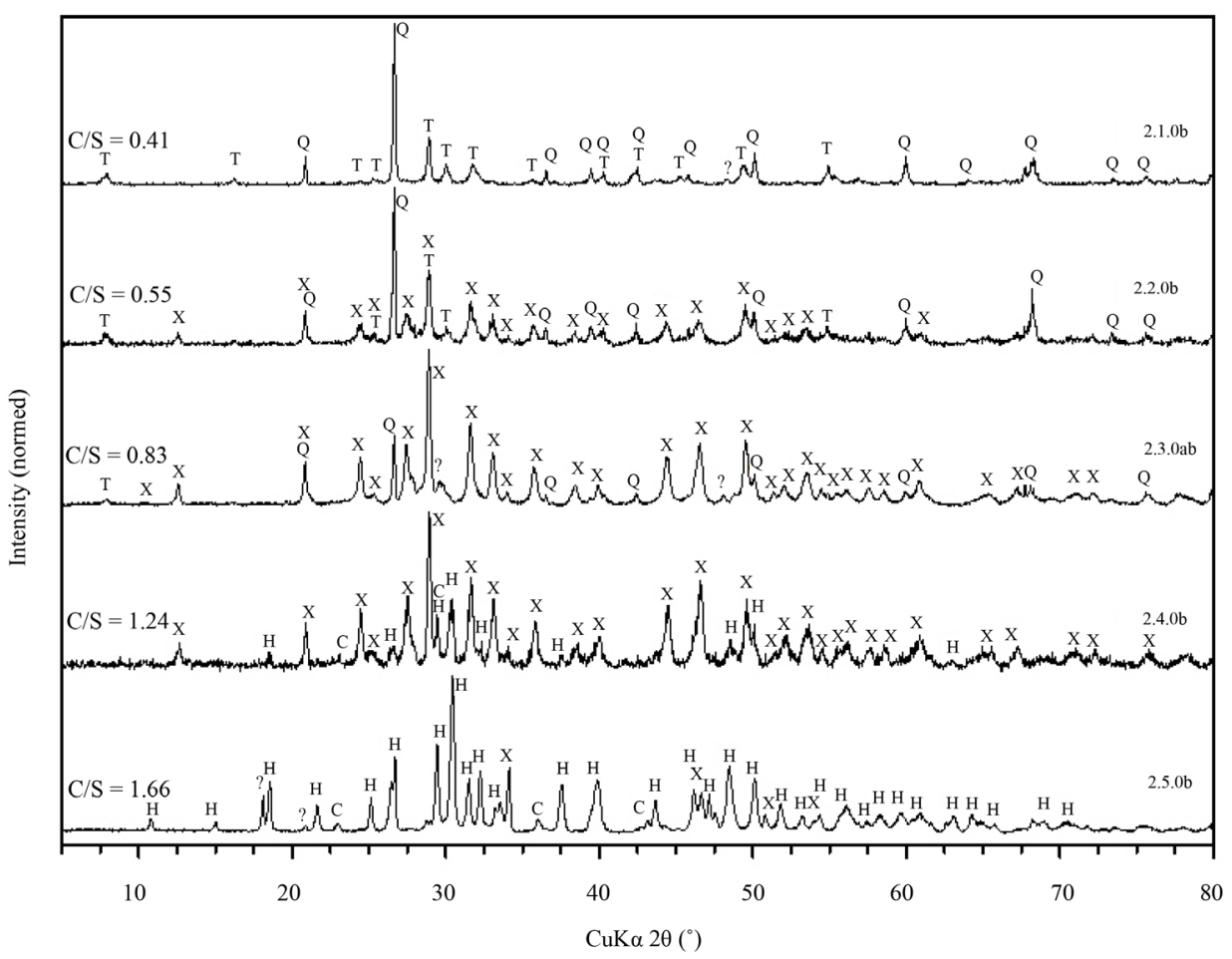

Figure 8. X-ray diffractogram of syntheses at $230^{\circ} \mathrm{C}$ (series $2 \mathrm{~b}$ ) with increasing $\mathrm{C} / \mathrm{S}$ ratio and constant CaO. Symbols: $11 \AA$ tobermorite $(\mathrm{T})$, xonotlite $(\mathrm{X})$, quartz $(\mathrm{Q})$, calcite $(\mathrm{C})$, portlandite $(\mathrm{P})$, unknown phase (?).

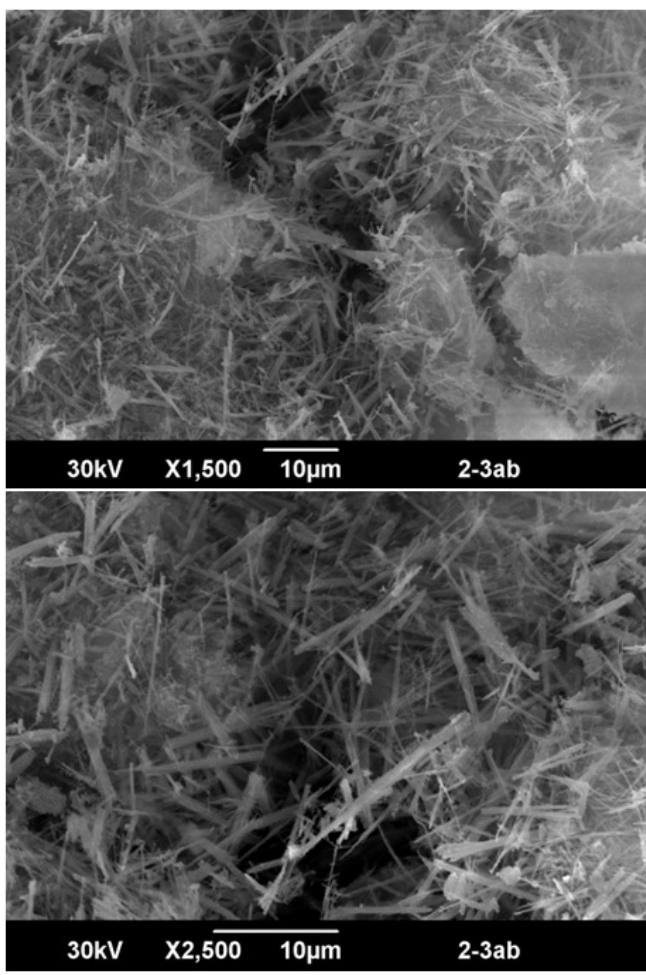

Figure 9. SEM image of sample $2.3 \mathrm{ab}$ with $1500 \mathrm{x}$ magnification (top), $230^{\circ} \mathrm{C}, \mathrm{C} / \mathrm{S}=0,83$, main phase xonotlite and SEM image of sample 2.3ab with $2500 \mathrm{x}$ magnification (bottom), $230^{\circ} \mathrm{C}, \mathrm{C} / \mathrm{S}=$ 0.83 , main phase xonotlite. 
The synthesis products of series 2 (sample 2.3ab, C/S ratio 0.83) show fine needle-like crystals of xonotlite. The needles have average lengths up to $9.2 \mu \mathrm{m}$. The crystals grew in clusters into the free pore space between the quartz cores.

The C/S ratio, estimated from EDX measurements of the crystals, is 1.17 (Figure 10), which is close to C/S of ideal xonotlite $(\mathrm{C} / \mathrm{S}=1.0)$.

Figure 11 give the SEM analyses of sample 2.5b.

Figure 11 shows the results of the SEM analysis of product 2.5b. The images illustrate small needle-like crystals of hillebrandite connected with small bladed calcite crystals. The EDX area analysis (Figure 12) yields to a $\mathrm{C} / \mathrm{S}$ ratio of 2.71, explained by the presence of calcite, which increases the $\mathrm{C} / \mathrm{S}$ ratio of ideal hillebrandite (2.0).

\subsection{FTIR-Spectroscopy}

The same best samples, already described below by Rietveld analysis of X-ray powder pattern and by SEM/ EDX investigation, were selected for the IR spectroscopic characterization:

- Sample 1.2a (tobermorite (Tob), $180^{\circ} \mathrm{C}, \mathrm{C} / \mathrm{S}=0.55$ );

- Sample 1.3ab (tobermorite and xonotlite (Tob \& Xo), $180^{\circ} \mathrm{C}, \mathrm{C} / \mathrm{S}=0.83$ );

- Sample 2.3ab (xonotlite (Xo), $230^{\circ} \mathrm{C}, \mathrm{C} / \mathrm{S}=0.83$ );

- Sample 2.5b (hillebrandite (Hil), $230^{\circ} \mathrm{C}, \mathrm{C} / \mathrm{S}=1.66$ ).

As a reference also natural $11 \AA$ tobermorite (from Zeilberg, Germany) and xonotlite (from former Yugoslavia) were measured. The results of the FTIR analysis are shown in Figure 13.

The spectra of samples 1.2a (tobermorite) and 1.3ab (tobermorite/xonotlite) and the measured natural $11 \AA$

Table 6. Quantitative phase analysis of the synthesis product $2.5 \mathrm{~b}$.

\begin{tabular}{ccc}
\hline Phase & Composition & Amount (M.-\%) \\
\hline hillebrandite & $\mathrm{Ca}_{2} \mathrm{SiO}_{3}(\mathrm{OH})_{2}$ & 89 \\
calcite & $\mathrm{CaCO}_{3}$ & 8 \\
quartz & $\mathrm{SiO}_{2}$ & 3 \\
\hline
\end{tabular}

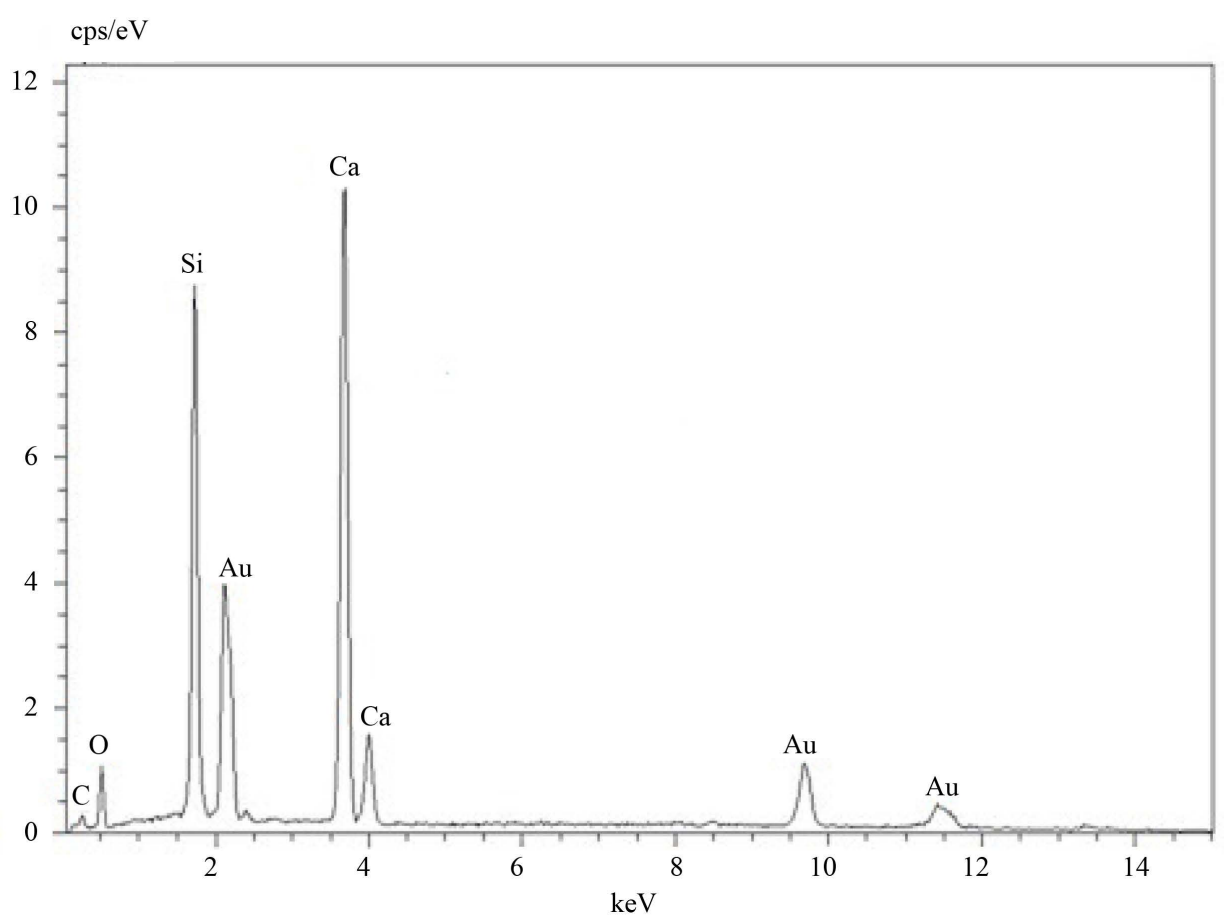

Figure 10. EDX spectrum of sample 2.3ab. 


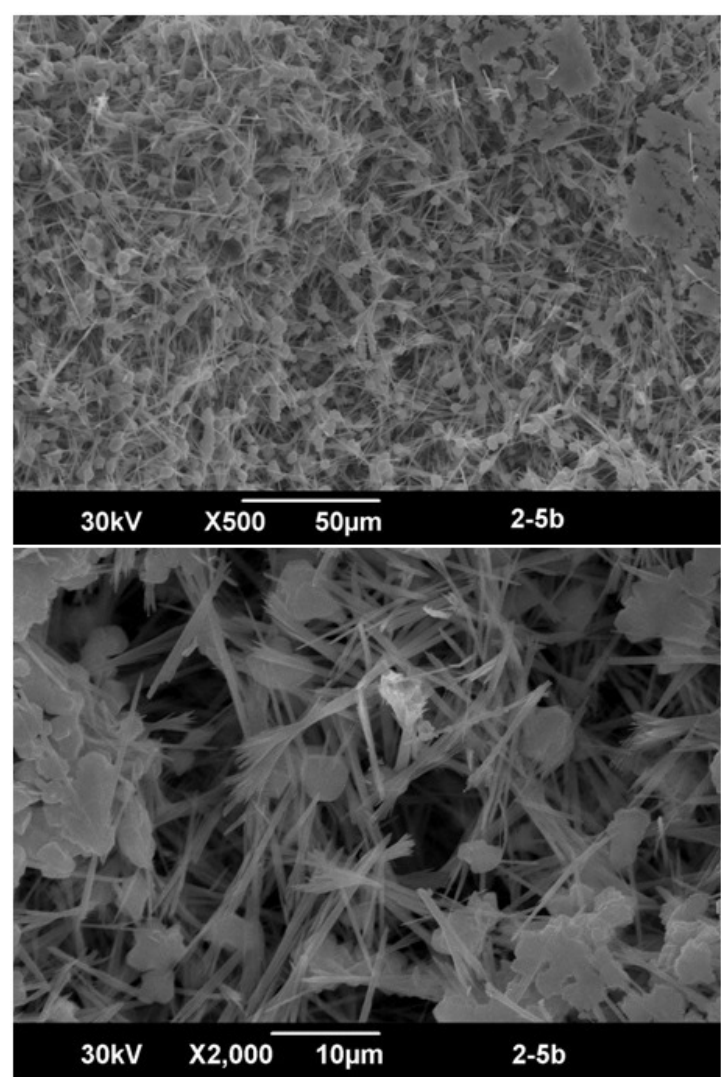

Figure 11. SEM image of sample $2.5 \mathrm{~b}$ with $500 \times$ magnification (top), $230^{\circ} \mathrm{C}, \mathrm{C} / \mathrm{S}=1.66$, main phase hillebrandite and SEM image of sample $2.5 \mathrm{~b}$ with $2000 \times$ magnification (bottom), $230^{\circ} \mathrm{C}, \mathrm{C} / \mathrm{S}=$ 1.66 , main phase hillebrandite.

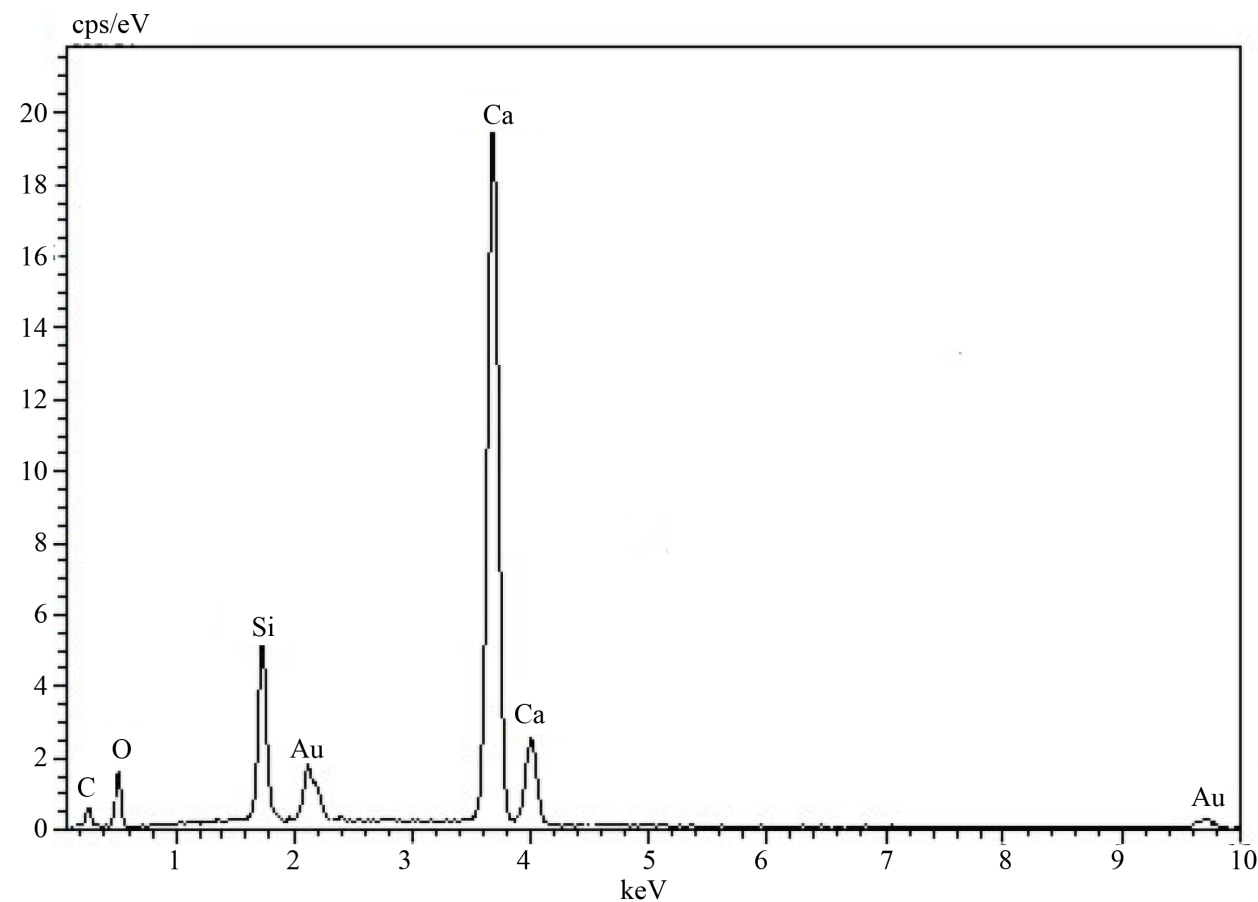

Figure 12. EDX spectrum of sample 2.5b. 


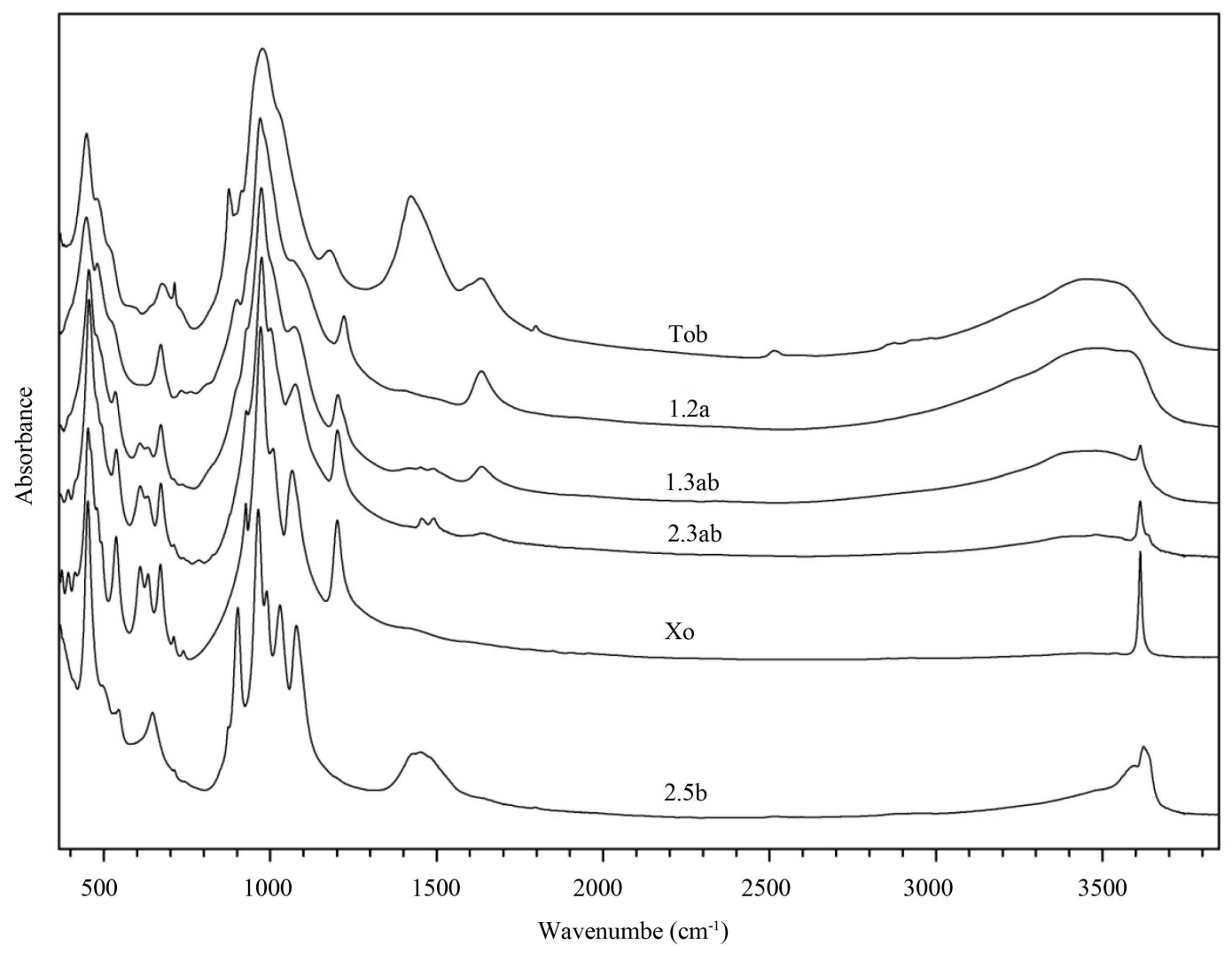

Figure 13. FTIR-spectra of syntheses 1.2a, 1.3ab, 2.3ab, 2.5b, natural $11 \AA$ tobermorite (Tob) and natural xonotlite (Xo).

tobermorite show the deformation vibrations of $\mathrm{SiO}_{4}$-tetrahedra at $400-650 \mathrm{~cm}^{-1}$. Intermolecular water is indicated by bands at $1633 \mathrm{~cm}^{-1}$ and $2700-3700 \mathrm{~cm}^{-1}$ [1] [7]. The FTIR spectra of the synthesized tobermorite (sample 1.2a and 1.3ab) compared with the natural $11 \AA$ tobermorite reveal differences in the Si-O stretching vibrations $\left(800-1200 \mathrm{~cm}^{-1}\right)$. The synthetic tobermorite (1.2a, 1.3ab) has sharper bands at lower wave number $\left(967 \mathrm{~cm}^{-1}\right)$ compared to the natural tobermorite $\left(975 \mathrm{~cm}^{-1}\right)$ [1] [7]. Impurities of carbonate $\left(\mathrm{CO}_{3}{ }^{2-}\right)$ within the spectrum of the natural $11 \AA$ tobermorite sample are detected by a broad band at $1422 \mathrm{~cm}^{-1}$ and a sharp signal at $876 \mathrm{~cm}^{-1}$. Both clearly show the impurities of calcite in the sample. OH-vibrations $\left(3618 \mathrm{~cm}^{-1}\right)$ in the spectrum of the synthetic sample 1.3ab belong to xonotlite (small amounts) [1] [7].

The synthetic sample 2.3ab (xonotlite) and the measured natural xonotlite sample show sharp bands of deformation of $\mathrm{SiO}_{4}$-tetrahedra $\left(400-500 \mathrm{~cm}^{-1}\right)$, of Si-O-Si-bending $\left(671 \mathrm{~cm}^{-1}\right)$ and $\mathrm{SiO}$-stretching vibrations (800 - $\left.1200 \mathrm{~cm}^{-1}\right)$. A sharp signal of OH-vibrations $\left(3614 \mathrm{~cm}^{-1}\right)$ is also seen [1] [4] [7]. In summary the spectrum of the synthetic sample 2.3ab correlates well with the spectrum of the natural xonotlite sample.

The sample of hillbrandite (2.5b) contains sharp bands of $\mathrm{OH}$ vibrations at $3624 \mathrm{~cm}^{-1}$ with a shoulder at 3591 $\mathrm{cm}^{-1}$. Also a number of five sharp Si-O-Si stretching bands $\left(900-1100 \mathrm{~cm}^{-1}\right)$ are seen. Only a sharp band at 452 $\mathrm{cm}^{-1}$ with small shoulders represents the internal deformation of the $\mathrm{SiO}_{4}$ tetrahedra. The Si-O-Si stretching vibration bands are located at $902 \mathrm{~cm}^{-1}, 964 \mathrm{~cm}^{-1}$ with a shoulder at $989 \mathrm{~cm}^{-1}, 1029 \mathrm{~cm}^{-1}$ and $1078 \mathrm{~cm}^{-1}$ [1] [7].

\section{3. ${ }^{29}$ Si MAS NMR-Spectroscopy}

The same synthetic samples 1.2a (Tob.), 1.3ab (Tob./Xo.), 2.3ab (Xo.) and 2.5 (Hil.), characterized by FTIR, were now analyzed by ${ }^{29} \mathrm{Si}$ MAS NMR spectroscopy. High resolution NMR spectroscopy of this nucleus was shown to be an appropriate method for structural characterization of CSH phases tobermorite [28] [29] as well as xonotlite and hillebrandite [30]. The results of the ${ }^{29} \mathrm{Si}$ MAS NMR spectroscopy of these samples are presented in Figure 14. 

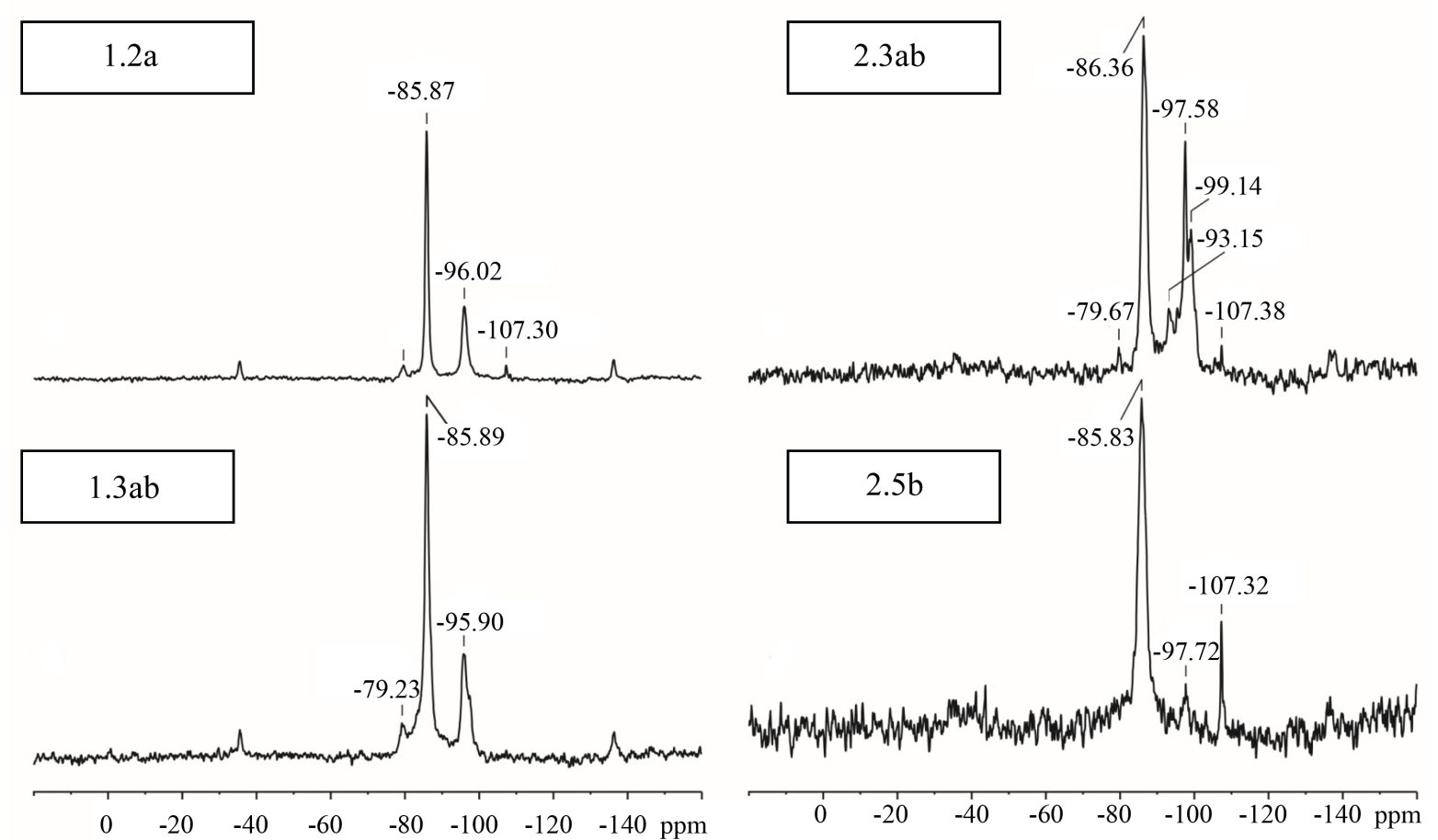

Figure 14. ${ }^{29}$ Si MAS NMR spectrum of samples 1.2a (Tob.), 1.3ab (Tob./Xo.), 2.3ab (Xo.) and 2.5 (Hil.).

\subsubsection{Sample 1.2a ( Tob, $\left.180^{\circ} \mathrm{C}, \mathrm{C} / \mathrm{S}=0.55\right)$}

The spectrum of sample 1.2a (Tob.) shows signals with chemical shifts at about $-79 \mathrm{ppm},-85.87 \mathrm{ppm},-96.02$ $\mathrm{ppm}$ and $-107.30 \mathrm{ppm}$. The strongest signal (-85.87) belongs to $\mathrm{Q}^{2}$-sites of a pairing tetrahedral, chain middle groups [28] [32]. This signal is three-times higher compared to the other signals. The peak at $-96.02 \mathrm{ppm}$ belongs to $\mathrm{SiO}_{4}$ tetrahedra $\left(\mathrm{Q}^{3}\right.$-sites) with three neighboured tetrahedra. The $\mathrm{Q}^{3}$-sites are due to the formation of double-chains, which are present in xontlite and tobermorite [1] [4] [16] [29]. The signal at $-107.30 \mathrm{ppm}$ belongs to the $\mathrm{Q}^{4}$-sites of quartz [29] [33]. The signal at $-79 \mathrm{ppm}\left(\mathrm{Q}^{1}\right.$-sites) represents chain end groups [32].

\subsubsection{Sample $1.3 \mathrm{ab}\left(\mathrm{Tob} \& \mathrm{Xo}, 180^{\circ} \mathrm{C}, \mathrm{C} / \mathrm{S}=0.83\right.$ )}

The strongest signal at $-85.89 \mathrm{ppm}$ represents $\mathrm{Q}^{2}$-sites of pairing $\mathrm{SiO}_{4}$ tetrahedra. Another strong signal at -95.90 ppm belongs to $\mathrm{Q}^{3}$-sites and a weak signal at $-79.23 \mathrm{ppm}$ to $\mathrm{Q}^{1}$-sites [32].

\subsubsection{Sample $2.3 \mathrm{ab}\left(\mathrm{Xo}, 230^{\circ} \mathrm{C}, \mathrm{C} / \mathrm{S}=0.83\right)$}

The strongest signal at $-86.36 \mathrm{ppm}$ represents $\mathrm{Q}^{2}$-sites. The signal at $-97.58 \mathrm{ppm}$ belongs to the $\mathrm{Q}^{3}$-sites. The

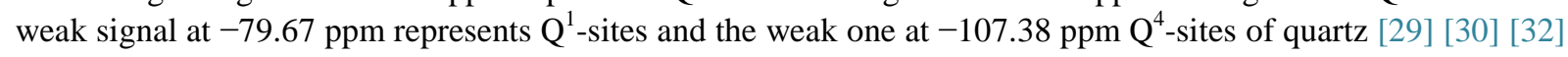
[33] quartz. The peaks at $-93.15 \mathrm{ppm}$ and $-99.14 \mathrm{ppm}$ are unknown (the signal at $-99.14 \mathrm{ppm}$ is close to the $\mathrm{Q}^{3}$-sites) [32].

\subsubsection{Sample $2.5 \mathrm{~b}\left(\mathrm{Hil}, 230^{\circ} \mathrm{C}, \mathrm{C} / \mathrm{S}=1.66\right.$ )}

The spectrum shows a strong signal of $\mathrm{Q}^{2}$-sites at $-85.83 \mathrm{ppm}$. The other signals at $-97.73 \mathrm{ppm}$ and -107.32 ppm belong to $\mathrm{Q}^{3}$-sites and quartz. The results correlate with the structure of the single-chain silicate hillebrandite [30].

\section{Conclusions}

The experiments clarified some important relations of crystallization process of $\mathrm{CSH}$-phases with the C/S ratio and the mass ratio of the educts in the temperature range of the tobermorite-xonotlite crossover reaction $\left(180^{\circ} \mathrm{C}\right.$ $\left.230^{\circ} \mathrm{C}\right)$. 
Remarkable temperature-depended differences of the crystallization behavior could be observed. At $180^{\circ} \mathrm{C}$ an increase of the C/S-ratio higher than 0.83 up to 1.66 retards the formation of CSH-phases (portlandite beside calcite and a small amount of quartz was analyzed). In contrast at $230^{\circ} \mathrm{C}$ xonotlite and hillebrandite occur even at high $\mathrm{C} / \mathrm{S}$ ratios.

The XRD results also show differences between the syntheses with constant mass of $\mathrm{SiO}_{2}$ (series $1 \mathrm{a}$ and $2 \mathrm{a}$ ) compared with experiments with constant mass of $\mathrm{CaO}(1 \mathrm{~b}$ and $2 \mathrm{~b})$. At $180^{\circ} \mathrm{C}$ the conversion of the educts with a constant mass of $\mathrm{SiO}_{2}$ was somewhat accelerated, compared with extent of reactions starting with educts of constant mass of $\mathrm{CaO}$. Higher amounts of remaining portions of quartz and lower conversion of the educts into $\mathrm{CSH}$ could be clearly observed in the latter case of the b-experiments and $0.41<\mathrm{C} / \mathrm{S}<0.83$.

In the same $\mathrm{C} / \mathrm{S}$ interval but at $230^{\circ} \mathrm{C}$ also an interesting effect was found. Here the extent of the crossover reaction of tobermorite and xonotlite was influenced. At constant mass of quartz the conversion of the educts into xonotlite was higher, compared to tobermorite. At the higher ratios $1.24<\mathrm{C} / \mathrm{S}<1.66$ the xonotlite:hillebrandite ratio is influenced and higher amounts of hillebrandite occur in the experiments with constant mass of lime and variation of quartz. Thus the parallel experiments with different mass ratios of the educts are an important tool to study the influence of time evaluation of supersaturation within the solution under the peculiarities of the retrograde solubility of lime but accelerated solubility of quartz. As all experiments were performed in the same $50 \mathrm{ml}$ PTFE-containers the total mass of the educts determined the diffusion space during phase formation and our "b-syntheses" yield to more restricted conditions for distinctive crystallization. This could explain that the "b-samples" show higher portions of remaining quartz, beside calcite and portlandite in the X-ray powder diffraction results, compared to the syntheses with constant $\mathrm{SiO}_{2}$ ("a-syntheses"). The role of the diffusion processes under the used experimental conditions needs to be investigated in more detail in further research work.

Summarizing the results of the present work, the best reaction parameters (temperature, C/S-ratio) regarding a reaction time of $40.5 \mathrm{~h}$ for the crystallization of $11 \AA$ tobermorite, xonotlite and hillebrandite are:

1) $11 \AA$ tobermorite: $180^{\circ} \mathrm{C}, \mathrm{C} / \mathrm{S}=0.55$; series with constant mass of $\mathrm{SiO}_{2}$;

2) xonotlite: $230^{\circ} \mathrm{C}, \mathrm{C} / \mathrm{S}=0.83$; series with constant mass of $\mathrm{SiO}_{2}$;

3) hillebrandite: $230^{\circ} \mathrm{C}, \mathrm{C} / \mathrm{S}=1.66$; series with constant mass of $\mathrm{CaO}$.

All CSH-phases and the course of reaction could be successfully described by using multiple complementary analytic methods XRD, SEM/EDX, FTIR- and ${ }^{29}$ Si MAS NMR-spectroscopy.

\section{Acknowledgements}

We are gratefully indebted to Dr. M. Fechtelkord, Bochum University, for the NMR measurements and many productive discussions of the spectra.

\section{References}

[1] Yu, P., Kirkpatrick, R.J., Poe, B., McMillan, P.F. and Cong, X.D. (1999) Structure of Calcium Silicate Hydrate (C-S-H): Near-, Mid-, and Far-Infrared Spectroscopy. Journal of the American Ceramic Society, 82, 742-748. http://dx.doi.org/10.1111/j.1151-2916.1999.tb01826.x

[2] Mörtel, H. (1980) Mineralbestand, Gefüge und physikalische Eigenschaften von Kalksandsteinen. Fortschritte der Mineralogie, 58, 37-67.

[3] Shaw, S., Clark, S.M. and Henderson, C.M.B. (2000) Hydrothermal Formation of the Calcium Silicate Hydrates, Tobermorite $\left(\mathrm{Ca}_{5} \mathrm{Si}_{6} \mathrm{O}_{16}(\mathrm{OH})_{2} \cdot 4 \mathrm{H}_{2} \mathrm{O}\right.$ and Xonotlite $\left(\mathrm{Ca}_{6} \mathrm{Si}_{6} \mathrm{O}_{17}(\mathrm{OH})_{2}\right)$ : An in Situ Synchrotron Study. Chemical Geology, 167, 129-140. http://dx.doi.org/10.1016/S0009-2541(99)00205-3

[4] Gundlach, H. (1973) Dampfgehärtete Baustoffe. Bauverlag GmbH, Wiesbaden und Berlin.

[5] Hartmann, A. (2004) Untersuchungen zum Kristallisationsverhalten und zur Morphologie von $11 \AA$ Tobermorit in Abhängigkeit der Reaktivität der Kieselsäurequelle und dem Ionenbestand der Hydrothermallösung. Dissertation, Fachbereich Geowissenschaften und Geographie, Universität Hannover, Hannover.

[6] Hartmann, A., Buhl, J.-C. and van Breugel, K. (2007) Structure and Phase Investigations on Crystallization of $11 \AA$ Tobermorite in Lime Sand Pellets. Cement and Concrete Research, 37, 21-31. http://dx.doi.org/10.1016/j.cemconres.2006.09.007

[7] Hartmann, A., Schulenberg, D. and Buhl, J.-C. (2015) Investigation of the Transition Reaction of Tobermorite to Xonotlite under Influence of Additives. Advances in Chemical Engineering, 5, 197-214. http://dx.doi.org/10.4236/aces.2015.52022 
[8] Megaw, H.D. and Kelsey, C.H. (1956) Crystal Structure of Tobermorite. Nature, 177, 390-391. http://dx.doi.org/10.1038/177390a0

[9] Hamid, S.A. (1981) The Crystal Structure of the $11 \AA$ Tobermorite $\mathrm{Ca}_{2,25}\left[\mathrm{Si}_{3} \mathrm{O}_{7,5}(\mathrm{OH})_{1,5}\right] 1 \mathrm{H}_{2} \mathrm{O}$. Zeitschrift für Kristallographie, 154, 189-198.

[10] Merlino, S., Bonacarssi, E. and Armbruster, T. (1999) Tobermorites: Their Real Structure and Order-Disorder (OD) Character. American Mineralogist, 84, 1613-1621.

[11] Merlino, S., Bonacarssi, E. and Armbruster, T. (2000) The Real Structures of Clinotobermorite and Tobermorite 9 Å: OD Character, Polytypes, and Structural Relationships. European Journal of Mineralogy, 12, 411-429. http://dx.doi.org/10.1127/0935-1221/2000/0012-0411

[12] Merlino, S., Bonacarssi, E. and Armbruster, T. (2001) The Real Structure of Tobermorite 11 A Normal and Anormalous Forms, OD Character and Polytypic Modifications. European Journal of Mineralogy, 13, 577-590. http://dx.doi.org/10.1127/0935-1221/2001/0013-0577

[13] Mamedov, K.S. and Belov, N.V. (1955) Structure of Xonotlite $\mathrm{Ca}_{6} \mathrm{Si}_{6} \mathrm{O}_{17}(\mathrm{OH})_{2}$. Doklady Akademii Nauk SSSR, 104, 615-618.

[14] Kudoh, Y. and Tukeuchi, Y. (1979) Polytypism of Xonotlite: (I) Structure of an A-1 Polytype. Mineralogical Journal, 9, 349-373. http://dx.doi.org/10.2465/minerj.9.349

[15] Hejny, C. and Armbruster, T. (2001) Polytypism in Xonotlite $\mathrm{Ca}_{6} \mathrm{Si}_{6} \mathrm{O}_{17}(\mathrm{OH})_{2}$. Zeitschrift für Kristallographie, 216, 396-408. http://dx.doi.org/10.1524/zkri.216.7.396.20363

[16] Churakov, S.V. and Mandaliev, P. (2008) Structure of the Hydrogen Bonds and Silica Defects in the Tetrahedral Double Chain of Xonotlite. Cement and Concrete Research, 38, 300-311. http://dx.doi.org/10.1016/j.cemconres.2007.09.014

[17] Heller, L. (1953) X-Ray Investigation of Hillebrandite. Mineralogical Magazine, 30, 150-154. http://dx.doi.org/10.1180/minmag.1953.030.221.09

[18] Dai, Y. and Post, J.E. (1995) Crystal Structure of Hillebrandite: A Natural Analogue of Calcium Silicate Hydrate (CSH) Phases in Portland Cement. American Mineralogist, 80, 841-844.

[19] Taylor, H.F.M. (1990) Cement Chemistry. Academic Press, London.

[20] Winkler, A. and Wieker, W. (1979) Über Synthese, Aufbau und thermisches Verhalten von $11 \AA$-Tobermorit. Zeitschrift für anorganische und allgemeine Chemie, 451, 45-56. http://dx.doi.org/10.1002/zaac.19794510108

[21] Winkler, A. and Wieker, W. (1982) Zum Ablauf der Hydrothermalreaktion von CaO und Quarz in Suspension bei $190^{\circ} \mathrm{C}$. Zeitschrift für anorganische und allgemeine Chemie, 490, 77-90. http://dx.doi.org/10.1002/zaac.19824900110

[22] Garbev, K. (2004) Struktur, Eigenschaften und quantitative Rietveldanalyse von hydrothermal kristallisierten Calciumsilikathydraten (C-S-H-Phasen). Dissertation, Wissenschaftliche Berichte, FZKA 6877, Forschungszentrum Karlsruhe in der Helmholtz-Gemeinschaft.

[23] Hartmann, A. and Buhl, J.-C. (2010) The Influence of Sucrose on the Crystallization in the System $\mathrm{CaO}^{-\mathrm{SiO}_{2-}}$ $\mathrm{C}_{12} \mathrm{H}_{22} \mathrm{O}_{11}-\mathrm{H}_{2} \mathrm{O}$ under Hydrothermal Conditions. Materials Research Bulletin, 45, 396-402. http://dx.doi.org/10.1016/j.materresbull.2009.12.033

[24] Hartmann, A., Khakhutov, M. and Buhl, J.-C. (2014) Hydrothermal Synthesis of CSH-Phases (Tobermorite) under Influence of Ca-Formate. Materials Research Bulletin, 51, 389-396. http://dx.doi.org/10.1016/j.materresbull.2013.12.030

[25] Black, L., Garbev, K. and Stumm, A. (2009) Structure, Bonding and Morphology of Hydrothermally Synthesized Xonotlite. Advances in Applied Ceramics, 108, 138-144. http://dx.doi.org/10.1179/174367608X353638

[26] Spudulis, E., Savareika, V. and Spokankas, A. (2013) Influence of Hydrothermal Synthesis Condition on Xonotilite Crystal Morphology. Materials Science (Medziagotyra), 19, 190-196.

[27] Meyer, K. (1977) Physikalisch-Chemische Kristallographie. Deutscher Vlg. für Grundstoffindustrie, Leipzig.

[28] Maeshima, T., Noma, H., Sakiyama, M. and Mitsuda, T. (2003) Natural 1.1 and 1.4 nm Tobermorites from Fuka, Okayama, Japan: Chemical Analysis, Cell Dimensions, ${ }^{29}$ SiNMR and Thermal Behavior. Cement and Concrete Research, 33, 1515-1523. http://dx.doi.org/10.1016/S0008-8846(03)00099-1

[29] Wieker, W., Grimmer, A.-R., Winkler, A., Mägi, M., Tarmak, M. and Lippmaa, E. (1982) Solid-State High-Resolution ${ }^{29}$ SiNMR Spectroscopy of Synthetic $14 \AA, 11 \AA$ and $9 \AA$ Tobermorites. Cement and Concrete Research, 12, 333-339. http://dx.doi.org/10.1016/0008-8846(82)90081-3

[30] Lippmaa, E., Mägi, M., Samoson, A., Engelhardt, G. and Grimmer, A.-R. (1980) Structural Studies of Silicates by Solid-State High Resolution ${ }^{29}$ SiNMR. Journal of the American Chemical Society, 102, 4889-4893. http://dx.doi.org/10.1021/ja00535a008

[31] International Centre for Diffraction Data, 12 Campus Boulevard, Newton Square, Pennsylvania 190073-3272, USA. 
[32] Richardson, I.G., Skibsted, J., Black, L. and Kirkpatrick, R.J. (2010) Characterization of Cement Hydrate Phases by TEM, NMR and Raman Spectroscopy. Advances in Cement Research, 22, 233-248. http://dx.doi.org/10.1680/adcr.2010.22.4.233

[33] Fechtelkord, M. (2014) Communicated. Institut für Geologie, Mineralogie und Geophysik, Ruhr-Universität Bochum. 